$\xi=$

\title{
Determination of viability in foodborne bacteria with inter-calating dyes: ethidium monoazide (EMA) and propidium monoazide (PMA)
}

\author{
A. Ezgi Telli *, Yusuf Doğruer \\ Selcuk University, Faculty of Veterinary Medicine, Department of Food Hygiene and Technology \\ *Corresponding author E-mail: ezgiyilmaz@selcuk.edu.tr
}

\begin{abstract}
The ability to distinguish between living and dead cells is considered to be very important for biological researches. It is an important problem that the technology used up to day does not allow the quantitative differentiation of specific cells in a mixed cell community. Determination of whether the microorganisms present in the foods are in a viable form is an important phenomenon in determining the disease-forming potential.

It is a fact that DNA, which is found in cells that lose their viability, can maintain its activity for a long time. Discrimination of live-dead cell occurs when the intercalating dye is covalently bound to DNA that is cleaved in the dead cell where membrane integrity is impaired. The formation of the covalent bond is activated by photoactivation. Inter-collating dyes only affect dead cells that are damaged by cell wall or membrane integrity. Due to the covalent binding of the inter-collating dye, DNA amplification cannot occur in PCR and other molecular techniques based on PCR.

Among the non-permeable stains, it is accepted that PI is the most commonly used. PMA is identical to PI and additionally contains azide groups. Azide groups allow PMA to cross-covalently bond with DNA in bright light. Another inter-collating dyes with an azide group is ethidium mono azide (EMA). The The PMA molecule provides a higher selectivity on discrimination of live-dead cells by virtue of its' higher charge when compared to EMA. Many researchers have combined EMA and PMA with PCR, Real-time PCR and LAMP in order to differentiate the live population of bacterial, viral, fungal and parasitic food-borne pathogens because they are claimed to be more successful in complex samples than in fluorescence based techniques.
\end{abstract}

Keywords: Ethidium Monoazide (EMA); Foodborne Bacterial Pathogens; Intercalating Dyes; Propidium Monoazide (PMA); Viability.

\section{Introduction}

The ability to distinguish between living and dead cells is considered very important for biological researches. It is an important problem that the technology used up to day does not allow the quantitative differentiation of specific cells in a mixed cell community. Determination of whether the microorganisms present in the foods are in a viable form is an important phenomenon in determining the disease-forming potential.

It is known that there are many molecules with the ability to chelate DNA and RNA bases. Among them, covalently attached, molecules are considered to be more advantageous than noncovalent molecules. Covalent binding molecules provide selective attachment to the nucleic acid. The binding sites of the covalently linked molecules and the changes in the region to which they are attached can be detected by sequencing methods. Psoralen and its derivatives from these molecules are described as substances that are photo chemically linked to nucleic acids and are considered useful in the studies of nucleic acid structure. Azide derivatives are also other group of molecules with similar properties. (Vladescu 2007, Biebricher 2015).

One of the earliest studies of ethidium bromide in azide groups belongs to Hixon et al (1975). Besides this, Bolton and Kearns (1978) observed for the first time that ethidium bromide is covalently linked photochemically to nucleic acids, while at the same time stimulating DNA repair mechanisms in human lymphocytes.

DNA-chelating dyes to have the property of changing the structure and mechanical properties of DNA. This structural change can complicate the enzymatic reactions in DNA. The complexity in this way is considered to be necessary to the functioning of chelating agents even though it is an unwanted condition in biochemical events. (Vladescu 2007, Biebricher 2015).

Discrimination of live-dead cell occurs when the membrane integrity of the inter-collating dyes is covalently bound to the DNA that is cleaved in the dead cell. The formation of covalent bond is occurred by photoactivation. Inter-collating dyes only react in dead cells that are damaged by cell wall or membrane integrity. Due to the covalent binding of the inter-collating dye, DNA amplification cannot occur and as a result of this. Detection is impossible in PCR and other molecular techniques based on PCR(Rudi et al 2005).

\section{Ethidium monoazide (EMA)}

Bolton and Kearns (1978) stated that the covalent binding of Ethidium Monoazide (EMA) to nucleic acids is a binding exactly the same as ethidium. Researchers have for the first time suggested that the EMA molecule can bind to nucleic acids up to $75 \%$ by the action of high-wavelength light. Besides this, they 
declared that the fluorescence of binding of EMA and ethidium to nucleic acids has the same environmental sensitivity indicates that this property of EMA can also be used as fluorescence photoaffinity markers of nucleic acids.

Ethidium monoazide (EMA) was first used by Nogva et al. (2003) to distinguish dead and living cells. The researchers used E. coli, Salmonella spp., and L. monocytogenes as the model microorganisms, and they obtained the dead and live cell suspensions with heat treatment and certain disinfectants at certain doses (96\% ethanol, 70\% isopropanol, 500 ppm benzalkonium chloride).Rudi Rudi et al. (2005) suggested that EMA-PCR was more successful in larger areas and complex specimens when compared to fluorescent-based standard techniques used to distinguish dead and live microorganisms of $\mathrm{C}$. jejuni.

In later times, many investigators (Regan et al 2003, Rudi et a 2005, Flekna et al 2007, Lu et al 2009, Wang et al 2009, Kobayashi et al 2009, Soejima et al 2011, Wang et al 2012, Wang \& Levin 2006, Liu et al 2012) combined the use of EMA with methods such as PCR, Realtime PCR, and LAMP to detect many bacterial (Table 1), viral, fungal and parasitic agents.

\section{Propidium monoazide (PMA)}

Propidium Monoazide (PMA) is a molecule formed by the chemical modification of Propidium Iodide (PI). The molecule is formed by the addition of an azide group at the phenothiazine ring. The azide groups under this condition are cross-linked under bright light. The similarity to PI provides the PMA with the selectivity of not to bind to live cells.

The photo induced binding of membrane integrity disrupted cells results in the DNA forming an insoluble compound and disassociating with cell debris during extraction procedures. Since DNA in living cells remains intact, DNA-based molecular methods produce a positive reaction (Nocker 2006).

The PMA is exposed to bright light after penetration and is crosscovalently bonded to damaged DNA. (Fig 1). These binding results in loss of amplification, resulting in DNA becoming an insoluble compound and giving a negative results in genomic DNA extraction. In this way, the PMA application allows a highly selective discrimination in a population of dead and living cells (Nocker et al 2006).

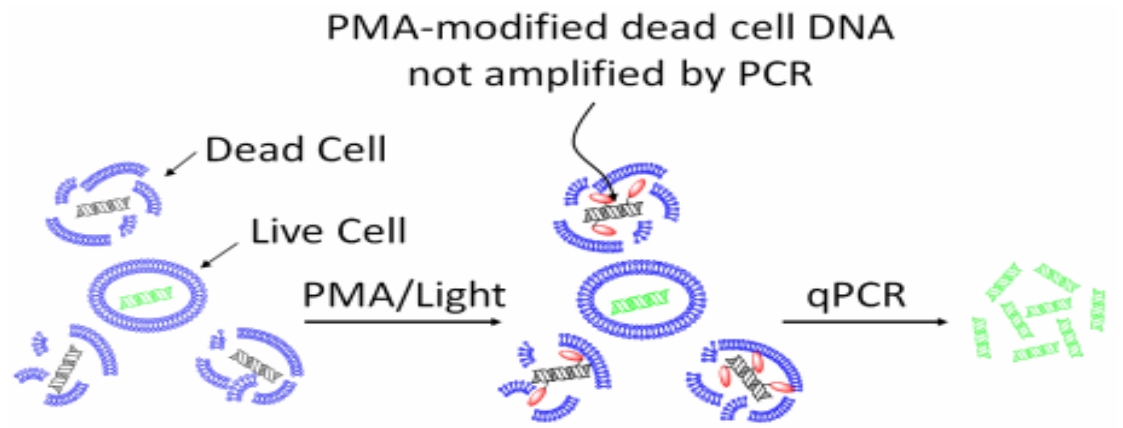

Fig. 1:Inhibition of PCR Amplification in PMA Applied Dead Cells (Nocker Et Al 2006). This Picture is from the Courtesy of Biotium, Inc.

PMA was first demonstrated in $E$. coli 0157:H7, $L$. monocytogenes, Micrococcus luteus, Mycobacterium avium, Pseudomonas syringe, Salmonella Typhimurium, Serratia marcescens, S. aureus and Streptococcus scombrines cells by Nocker et al (2006) suggesting that it provides superior selectivity in cells with impaired membrane integrity with high penetration.

In recent years, there have been many studies of PMA used for the determination of viability of food-borne microorganisms from intercalating dyes(Garcia-Cayuela et al 2009, Rawsthorne et al 2009, Josefsen et al 2010, Kralik et al 2010, Taskin et al 2010 , Chen et al 2011, Lovdal et al 2011, Elizaquivel et al 2012, Fujimoto \& Watanabe 2013, Gensberger et al 2013, Zhang et al 2014, Banihashemi et al 2015).

Garcia-Cayuela et al (2009) studied the quantitative evaluation of live cells by PMA-qPCR in mixed cultures of lactic acid bacteria (Lactobacillus acidophilus, Lactobacillus delbrueckii subsp. bulgaricus, Lactobacillus casei subsp. casei, Streptococcus thermophilus) and Bifidobacterium lactis in fermented dairy products. In the study decrease, of live microorganism was observed with PMA-qPCR and classical cultural method in fermented milk stored at $4{ }^{\circ}$ C.The results of the two methods were found similar and linear correlations were observed (0.995).The The researchers declared that the PMA-real-time PCR method was more advantageous in terms of yielding in as little as three hours than the classic cultural methodology that requires a three-day period to obtain results.

Rawsthorne et al (2009) used PMA as an intercalator in their study aimed at molecular detection of Bacillus subtilis spores in vivo and inactive form. The researchers found that the results of PMAqPCR and classical method, which identify the survivors of microorganisms that applied thermal inactivation stress, were consistent and statistically different from real-time PCR results without PMA.

Chen et al (2011) used PMA and LAMP methods in combination to determine the number of live Salmonella spp cells. In experiments in which melon, spinach and tomato were experimentally contaminated, inactivation of the microorganism was confirmed by PMA-LAMP method in suspensions containing microorganisms inactivated by heat treatment at concentrations up to $10^{8} \mathrm{CFU} / \mathrm{ml}$. The researchers found that PMA-LAMP had similar results with PMA-qPCR, besides these 100 times more sensitive than PMA-PCR.

In another study Elizaquivel et al (2012) wanted to detect live $E$. coli $\mathrm{O} 157: \mathrm{H} 7$, Salmonella spp. and L. monocytogenes cells in a mixed suspension. Researchers have primarily identified optimal concentrations of PMA and reagent D compounds which they have combined with qPCR. In the study, both reagents were found to provide a similar decrease in the number of pathogens detected, but in the rest of the study only PMA was applied to these microorganisms as reagent D was found toxic to the Salmonella and $L$. monocytogenes cells. The researchers have determined the optimal PMA concentration to be used for viability determination of inoculated microorganisms in spinach and mixed salad as 50 $\mu \mathrm{M}$, and they claimed that PMA-qPCR was an appropriate method for determining the viable microorganism counts in fresh vegetables.

Zhang et al (2014) used PMA to identify live cells in a multiplex PCR (mPCR) method for the detection of emetic and non-emetic Bacillus cereus groups. Limit of Detection (LOD) was determined as $4.0 \times 10^{2} \mathrm{KOB} / \mathrm{ml}$ in cultures containing dead microorganisms without PMA, $7.5 \times 10^{0} \mathrm{CFU} / \mathrm{ml}$ in cultures containing viable microorganisms and $7.5 \times 10^{1} \mathrm{CFU} / \mathrm{ml}$ in live cultures treated with PMA. The LOD value of experimentally contaminated samples was determined as $1.0 \times 10^{3} \mathrm{CFU} / \mathrm{g}$.

Banihashemi et al (2015) compared qPCR and PMA-qPCR methods in order to determine the viability of enteric pathogens in a river used as the drinking water source in Canada's Southern Ontario region. In the study conducted with Salmonella enterica, thermophilic Campylobacter spp., E. coli O157: H7 and Arcobacter butzleri microorganisms, the ratio of dead microorganisms detected in river water was found to be very low and the difference between living and total numbers was found to 
be only about $0.5 \log \mathrm{CFU} / \mathrm{ml}$. The researchers expressed PMAqPCR as a reliable method for the quantitative determination of live microorganisms in surface waters.

\section{Comparison of ethidium monoazide (EMA) with propidium monoazide (PMA)}

In the first study of PMA has been applied to distinguish cell viability by Nocker et al (2006), have suggested that PMA is more advantageous because of its higher selectivity compared to EMA The researchers attributed this to the penetration of EMA into living cells in some bacterial species. Although transport pumps bring EMA out of the cell with the help of metabolic activity in living cells, it still causes a large amount of DNA loss by the action of residual EMA. Because PMA has a higher load than the EMA (Fig 1), it does not pass through the intact cell membrane, which is considered to be an inhibitory effect of DNA loss (Nocker et al 2006). Nocker and Camper (2006) have stated that EMA, which they have tested in E. coli O157: H7, causes loss of nearly $60 \%$ of living cells.

Among the non-permeable dyes, it is considered that PI is the most commonly used. PMA, in addition to being identical to PI, it additionally contains azide groups. Azide groups also allow the PMA to cross-covalently bond with DNA in bright light. The PMA molecule has a higher load when compared to EMA (Fig. 2) and has the advantage of being able to stain dead cells with higher selectivity (Nocker 2006).

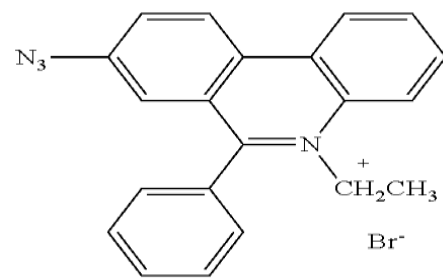

Ethidium Monoazide Bromide (EMA)

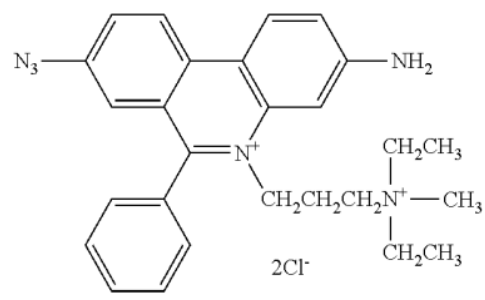

Propidium Monoazide (PMA)

Fig. 2: Molecular Formulas of EMA and PMA (Myron Et Al 2012).

There are a number of studies using EMA and PMA comparatively (Nam et al 2011, Pan and Breidt 2007, Cawthorn and Witthuhn 2008). (Table 1)

Nam et al (2011) used PMA and EMA comparatively in order to distinguish in the suspension of living and dead Helicobacter pylori cells. Researchers have observed that in experiments performed at a concentration of 1-100 $\mu \mathrm{M}$, PMA causes maximum dead cell detection and minimal viable cell loss at a concentration of $50 \mu \mathrm{M}$., On the other hand, it is indicated that penetration of EMA into both living and dead cells led to degradation of genomic DNA of bacteria. As a result, researchers have suggested that PMA should be used instead of EMA for the viability of $H$. pylori cells. Pan and Breidt (2007) analyzed the sensitivity of PMA-qPCR and EMA-qPCR in the detection of live $L$. monocytogenes cells and found that the ratio of dead cell concentration to live cell was less than $10^{4} \mathrm{CFU} / \mathrm{ml}$ and the viable cell concentration was more than $10^{3} \mathrm{CFU} / \mathrm{ml}$. The researchers declared that the use of PMA for viability detection was more appropriate as a result of their findings. Researchers who achieved the same results in suspensions prepared from bacterial broth cultures and biofilms also found that EMA had a higher rate of penetration to live cells as well as dead cells when compared to PMA. Researchers who have set out here have found that the combination of PMA and qPCR is suitable for use in food, medicine and environmental samples. Researchers who have set out here have found that the combination of PMA and qPCR is suitable for use in food, medicine and environmental samples.

Cawthorn and Witthuhn (2008) applied PMA and EMA at different concentrations $\left(10,50,100 \mu \mathrm{g} \mathrm{m}^{-1}\right)$ for dead and live cell suspension of Enterobacter sakazakii. At 50 and $100 \mu \mathrm{g} \mathrm{ml}^{-1}$ concentrations, PMA completely blocked PCR amplification in dead cells. Only live cells were amplified in live / dead cell suspensions at different concentrations of EMA. Researchers have shown that although EMA does have the same effect on PMA in dead cells, it has also an inhibitory effect on amplification of living cells.

Table 1: PMA and EMA Based Studies in Foodborne Bacterial Pathogens

\begin{tabular}{|c|c|c|c|}
\hline Bacterial Species & Method & $\begin{array}{l}\text { Inter- } \\
\text { calating } \\
\text { Dye }\end{array}$ & Reference \\
\hline $\begin{array}{l}\text { C. jejuni, L. } \\
\text { monocytogenes }\end{array}$ & qPCR & EMA & $\begin{array}{l}\text { Flekna et al } \\
2007\end{array}$ \\
\hline Salmonella spp. & LAMP & EMA & Lu et al 2009 \\
\hline E. coli $\mathrm{O} 157: \mathrm{H} 7$ & qPCR & EMA & $\begin{array}{l}\text { Wang et al } \\
2009\end{array}$ \\
\hline S.aureus, S.epidermidis & qPCR & EMA & $\begin{array}{l}\text { Kobayashi et } \\
\text { al } 2009\end{array}$ \\
\hline Enterobacteriaceae & PCR & EMA & $\begin{array}{l}\text { Soejimaet al } \\
2011\end{array}$ \\
\hline V. parahaemolyticus & LAMP & EMA & $\begin{array}{l}\text { Wang et al } \\
2012\end{array}$ \\
\hline H. pylori & qPCR & EMA/PMA & $\begin{array}{l}\text { Nam et al } \\
2011\end{array}$ \\
\hline $\begin{array}{l}\text { P. aeruginosa, } \\
\text { L.monocytogenes, } S . \\
\text { Typhimurium, } S . \\
\text { marcescens, E. coli } \\
\text { O157:H7 }\end{array}$ & $\begin{array}{l}\text { DNA } \\
\text { Microarray }\end{array}$ & PMA & $\begin{array}{l}\text { Nocker et al } \\
2009\end{array}$ \\
\hline P. aeruginosa & FISH & EMA & $\begin{array}{l}\text { Regan et al } \\
2003\end{array}$ \\
\hline V. vulnificus & qPCR & EMA & $\begin{array}{l}\text { Wang and } \\
\text { Levin } 2006\end{array}$ \\
\hline MRSA & $\begin{array}{l}\text { Microfluidic } \\
\text { Sistem- PCR }\end{array}$ & EMA & $\begin{array}{l}\text { Liu et al } \\
2012\end{array}$ \\
\hline E. coli & qPCR & PMA & $\begin{array}{l}\text { Taskin et al } \\
2010\end{array}$ \\
\hline Bifidobacterium bifidum & qPCR & PMA & $\begin{array}{l}\text { Fujimoto and } \\
\text { Watanabe } \\
2013\end{array}$ \\
\hline E.sakazakii & PCR & EMA/PMA & $\begin{array}{l}\text { Cawthorn } \\
\text { and Witthuhn } \\
2008\end{array}$ \\
\hline B.subtilis & qPCR & PMA & $\begin{array}{l}\text { Rawsthorne } \\
\text { et al } 2009\end{array}$ \\
\hline Campylobacter spp. & qPCR & PMA & $\begin{array}{l}\text { Josefsen et al } \\
2010\end{array}$ \\
\hline L. іппосиа & qPCR & PMA & $\begin{array}{l}\text { Lovdal et al } \\
2011\end{array}$ \\
\hline MAP & $\mathrm{qPCR}$ & PMA & $\begin{array}{l}\text { Kralik et al } \\
2010\end{array}$ \\
\hline Salmonellae & LAMP & PMA & $\begin{array}{l}\text { Chen et al } \\
2011\end{array}$ \\
\hline $\begin{array}{l}\text { E. coli } \mathrm{O} 157: \mathrm{H} 7 \text {, } \\
\text { Salmonella } \\
\text { L.monocytogenes }\end{array}$ & qPCR & PMA & $\begin{array}{l}\text { Elizaquivel } \\
\text { et al } 2012\end{array}$ \\
\hline B. cereus & mPCR & PMA & $\begin{array}{l}\text { Zhang et al } \\
2014\end{array}$ \\
\hline E. coli, $P$. aeruginosa & $\mathrm{qPCR}$ & PMA & $\begin{array}{l}\text { Gensberger } \\
\text { et al } 2013\end{array}$ \\
\hline $\begin{array}{l}\text { S. enterica, } \\
\text { Campylobacter, E.coli } \\
\mathrm{O} 157: \mathrm{H} 7, \text { A.butzleri }\end{array}$ & qPCR & PMA & $\begin{array}{l}\text { Banihashemi } \\
\text { et al } 2015\end{array}$ \\
\hline
\end{tabular}

FISH: Fluorescent In Situ Hybridization, MRSA: Methicillin-Resistant S.aureus, MAP: Mycobacterium avium subsp. Paratuberculosis, mPCR: Multiplex PCR 


\section{Conclusion}

When considered within the context of food safety, it should be taken into account that VBNC forms as well as live forms of food borne pathogens are also likely to cause disease. Hereby it is considered that differentiating the VBNC form by the intercollating dyes may provided a more realistic risk analysis of bacterial pathogens. As a conclusion, it is suggested that these and similar methods for determining viability should be used more widely in food microbiology.

\section{References}

[1] Banihashemi A1, Van Dyke MI, Huck PM (2012). Long-amplicon propidium monoazide-PCR enumeration assay to detect viable Campylobacter and Salmonella. J Appl Microbiol, 113:4, 863-73. https://doi.org/10.1111/j.1365-2672.2012.05382.x.

[2] Biebricher AS, Heller I, Roijmans RFH, Hoekstra TP, Peterman EJG, Wuite GJL (2015). The impact of DNA intercalators on DNA and DNA-processing enzymes elucidated through force-dependent binding kinetics. Nat Commun, 6:7304, 1-12. https://doi.org/10.1038/ncomms8304.

[3] Bolton PH, Kearns DR (1978). Spectroscopic properties of ethidium monoazide: a fluorescent photoaffinity label for nucleic acids. Nucleic Acids Res, 5:12, 4891-903. https://doi.org/10.1093/nar/5.12.4891.

[4] Cawthorn DM, Witthuhn RC (2008). Selective PCR detection of viable Enterobacter sakazakii cells utilizing propidium monoazide or ethidium bromide monoazide. J Appl Microbiol, 105:4, 1178-85. https://doi.org/10.1111/j.1365-2672.2008.03851.x.

[5] Chen S, Wang F, Beaulieu JC, Stein RE, Ge B (2011). Rapid detection of viable salmonellae in produce by coupling propidium monoazide with loop-mediated isothermal amplification, Appl Environ Microbiol, 77:12, 4008

[6] Elizaquivel P, Sánchez G, Selma MV, Aznar R (2012). Application of propidium monoazide-qPCR to evaluate the ultrasonic inactivation of Escherichia coli $\mathrm{O} 157: \mathrm{H} 7$ in fresh-cut vegetable wash water. Food Microbiol, 30:1, 316-20. https://doi.org/10.1016/j.fm.2011.10.008.

[7] Flekna G, Stefanic P, Wagner M, Smulders FJM, Mozina SS, Hein I (2007). Insufficient differentiation of live and dead Campylobacter jejuni and Listeria monocytogenes cells by ethidium monoazide (EMA) compromises EMA/real-time PCR. Res Microbiol, 158:5, 405-12. https://doi.org/10.1016/i.resmic.2007.02.008

[8] Fujimoto J, Watanabe K (2013). Quantitative detection of viable Bifidobacterium bifidum BF-1 cells in human feces by using propidium monoazide and strain-specific primers. Appl Environ Microbiol, 79:7, 2182-8. https://doi.org/10.1128/AEM.03294-12.

[9] Garcia-Cayuela T, Tabasco R, Peláez C, Requena T (2009) Simultaneous detection and enumeration of viable lactic acid bacteria and bifidobacteria in fermented milk by using propidium monoazide and real-time PCR. Int Dairy J, 19:6-7, 405-9. https://doi.org/10.1016/j.idairyj.2009.02.001.

[10] Gensberger ET, Sessitsch A, Kostic T (2013) Propidium monoazide-quantitative polymerase chain reaction for viable Escherichia coli and Pseudomonas aeruginosa detection from abundant background microflora. Anal Biochem, 441:1, 69-72. https://doi.org/10.1016/j.ab.2013.05.033.

[11] Hixon SC, White Jr WE, Yielding KL (1975). Selective covalent binding of an ethidium analog to mitochondrial DNA with production of petite mutants in yeast by photoaffinity labelling. $\mathrm{J}$ Mol Biol, 92:2, 319-29. https://doi.org/10.1016/0022 2836(75)90231-4.

[12] Josefsen MH, Löfström C, Hansen TB, Christensen LS, Olsen JE Hoorfar J (2010). Rapid quantification of viable Campylobacter bacteria on chicken carcasses, using real-time PCR and propidium monoazide treatment, as a tool for quantitative risk assessment. Appl Environ $\quad$ Microbiol, 76:15, 5097-104. https://doi.org/10.1128/AEM.00411-10.

[13] Kobayashi H, Oethinger M, Tuohy MJ, Hall GS, Bauer TW (2009). Unsuitable distinction between viable and dead Staphylococcus aureus and Staphylococcus epidermidis by ethidium bromide monoazide. Lett Appl Microbiol, 48:5, 633-8. https://doi.org/10.1111/j.1472-765X.2009.02585.x.

[14] Kralik P, Nocker A, Pavlik I (2010). Mycobacterium avium subsp paratuberculosis viability determination using F57 quantitative
PCR in combination with propidium monoazide treatment. Int $\mathrm{J}$ Food Microbiol, 141, 80-6. https://doi.org/10.1016/j.ijfoodmicro.2010.03.018.

[15] Liu YH, Wang CH, Wu JJ, Lee GB (2012). Rapid detection of live methicillin-resistant Staphylococcus aureus by using an integrated microfluidic system capable of ethidium monoazide pre-treatment and molecular diagnosis. Biomicrofluidics, 6:3, 034119.

[16] Lovdal T, Hovda MB, Björkblom B, Møller SG (2011). Propidium monoazide combined with real-time quantitative PCR underestimates heat-killed Listeria innocua. J Microbiol Methods, 85:2, 164-9. https://doi.org/10.1016/j.mimet.2011.01.027.

[17] Lu Y, Yang W, Shi L, Li L, Alam MJ, Guo S, Miyoshi S (2009). Specific detection of viable Salmonella cells by an ethidium monoazide-loop mediated isothermal amplification (EMA-LAMP) method, J Health Sci, 55, 820-4. https://doi.org/10.1248/jhs.55.820.

[18] Myron TLD, Venkateswaran KJ, Mohapatra B (2012). US20120231961 A1

[19] Nam S, Kwon S, Kim MJ, Chae JC, Jae Maeng P, Park JG, Lee GC (2011). Selective detection of viable Helicobacter pylori using ethidium monoazide or propidium monoazide in combination with real-time polymerase chain reaction. Microbiol Immunol, 55:12, 841-6. https://doi.org/10.1111/j.1348-0421.2011.00388.x.

[20] Nocker A, Camper AK (2006). Selective Removal of DNA from Dead Cells of Mixed Bacterial Communities by Use of Ethidium Monoazide. Appl Environ Microbiol, 72:3, 1997-2004. https://doi.org/10.1128/AEM.72.3.1997-2004.2006.

[21] Nocker A, Cheung CY, Camper AK (2006). Comparison of propidium monoazide with ethidium monoazide for differentiation of live vs. dead bacteria by selective removal of DNA from dead $\begin{array}{llll}\text { cells. J Microbiol } & \text { Methods, 67, }\end{array}$ https://doi.org/10.1016/j.mimet.2006.04.015.

[22] Nogva HK, Dromtorp SM, Nissen H, Rudi K (2003). Ethidium monoazide for DNA-based differentiation of viable and dead bacteria by 5'-nuclease PCR. Biotechniques, 34:4, 804-13.

[23] Rawsthorne H, Dock CN, Jaykus LA (2009). PCR-based method using propidium monoazide to distinguish viable from nonviable Bacillus subtilis spores. Appl Environ Microbiol, 75:9, 2936-9. https://doi.org/10.1128/AEM.02524-08.

[24] Regan JM, Oldenburg PS, Park HD, Harrington GW, Noguera DR (2003). Simultaneous determination of bacterial viability and identity in biofilms using ethidium monoazide and fluorescent in situ hybridization. Water Sci Technol, 47:5, 123-8.

[25] Rudi K, Moen B, Dromtorp SM, Holck AL (2005). Use of ethidium monoazide and PCR in combination for quantification of viable and dead cells in complex samples. Appl Environ Microbiol, 71:2, 1018-24. https://doi.org/10.1128/AEM.71.2.1018-1024.2005.

[26] Soejima Takashi, Iida K, Qin T, Taniai H, Seki M, Yoshida S (2008). Method to detect only live bacteria during PCR amplification. J. Clin. Microbiol. 46:2305-2313 https://doi.org/10.1128/JCM.02171-07.

[27] Taskin B, Gozen AG, Duran M (2011). Selective quantification of viable Escherichia coli bacteria in biosolids by quantitative PCR with propidium monoazide modification. Appl Environ Microbiol, 77:13, 4329-35. https://doi.org/10.1128/AEM.02895-10.

[28] Vladescu ID, McCauley MJ, Nuñez ME, Rouzina I, Williams MC (2007). Quantifying force-dependent and zero-force DNA intercalation by single-molecule stretching. Nat Methods, 4, 51722. https://doi.org/10.1038/nmeth1044.

[29] Wang L, Mustapha Y, Li A (2009). Detection of viable Escherichia coli $\mathrm{O} 157: \mathrm{H} 7$ by ethidium monoazide real-time PCR. J Appl Microbiol, 107:5, 1719-28. https://doi.org/10.1111/j.13652672.2009.04358.x.

[30] Wang L, Zhong Q, Li Y (2012). Ethidium monoazide-loop mediated isothermal amplification for rapid detection of Vibrio parahaemolyticus in viable but non-culturable state. Energy Procedia, 17, 1858-63. https://doi.org/10.1016/j.egypro.2012.02.323.

[31] Wang S, Levin RE (2006). Discrimination of viable Vibrio vulnificus cells from dead cells in real-time PCR. J Microbio Methods, 64:1, 1-8. https://doi.org/10.1016/j.mimet.2005.04.023.

[32] Zhang Z, Wang L, Xu H, Aguilar ZP, Liu C, GanB, Xiong Y, Lai W, Xu F, Wei H(2014). Detection of non-emetic and emetic Bacillus cereus by propidium monoazide multiplex PCR (PMA$\mathrm{mPCR}$ ) with internal amplification control. Food Cont, 35:1, 401-6. https://doi.org/10.1016/j.foodcont.2013.07.035. 